によって影響を受ける可能性のあること, 雾囲気ガスの 拡散，対流および圧力などが通常の分析の場合と異なる ことなどがあり，これらの問題については将来検討が必 要である.

電極物質の消耗量は, $B, C, V^{\frac{3}{2}}$ 飞比例し, $R$ 飞逆比 例する。また $L$ に注とえぞ無関係である。したがっ $\tau$, 電極物質の消耗量は放電電流の平均值に比例するこ
とがわかった。

Raiskii spark 放電の場合には，平均電流を測定する ととができなかった．そのため，電極物質の消耗量が平 均電流だけで規定され，発光装置の種類に無関係である ということは証明することができなかった。 Raiskii spark の放電回路の電気的特性についてはさらに検討す る必要がある.

鈴木：試作せる時間分解測光装圈

\title{
試作せる時間分解測光装置
}

鈴 木 範 人*

（昭和 39 年 9 月 30 日受理）

\section{A Time-Resolved Photometer}

\section{Norihito SUZUKI}

(Shimadzu Seisakusho Ltd.)

(18, Nishinokyo-Kuwabara-Machi, Chukyoku, Kyoto

A time-resolved photometer is devised to make time-resolved measurements of low intensity spectra. The time resolution is made by applying a gate pulse on dynodes of a photomultiplier and the photocurrent of the photomultiplier is measured with an electrometer. The limit of the time resolution of this system is $2 \mu \mathrm{sec}$. and excellent stability is obtained by a proper setting of the gate pulse voltage.

\section{1. 緒言}

光電子増倍管にゲートパルスを印加し，時間分解分光 測光を行なら方法は古くから行なわれている.との方法 の長所は, 微少光量の時間分解測光が可能であるという ことから，われわれは微小光量の測定を行なうため, 最 も簡単な回路構成を採ることを目標として，ゲートパル スによる時間分解測光装置の試作を行なった。

光電子増倍管に, パルスでゲート動作をさせる方法と して，光電子増倍管に印加する高電圧をパルスにする方 法 ${ }^{1)}$ 之, 光電子增倍管の 2 次電子放射電極に ゲート動作 を行なう方法2 があるが，われわれは，2 次電子放射電 極にゲート動作をさせる方法を採用した。

* 島津製作所科学器械工場第一技術課（京都市中京区 西 / 京桑原町 18).

1) A. V. Phelps and J. L. Pack: Rev. Sci. Instrum. 26, 45 (1955).

2) 近璋三; 応用物理 27, 551 (1958).
ここでは，試作したゲートパルス発生装置の詳細，お よび光電子増倍管のゲート動作特性などについての報告 を行なう・ゲート動作特性は Venetian blind 形の 2 次 電子放射電極を持ったものと， RCA 形のものでは異な っているが，後者に関しては南らの報告 ${ }^{2,3)}$ があるので, ここでは，前者に関するものにとどめる.

\section{2. 回 路 構 成}

この装置は，現像がおこっている任意の瞬間にゲート を開いて測光を行なうという目的を持った装置であるの で，現象が開始されたことを知るための検出部と，ゲー 卜を開く位相を決定する遅延回路とゲートパルスを発 生する部分，および光電子増倍管にゲートパルスを印加 する部分から構成される。

光電子増倍管の 2 次電子放射電極にゲート動作をさせ るためには，2 次電子放射電極の電位配置を正常な状態

3）南 茂夫・西川勝彦・吉永 弘：応用物理 33. 

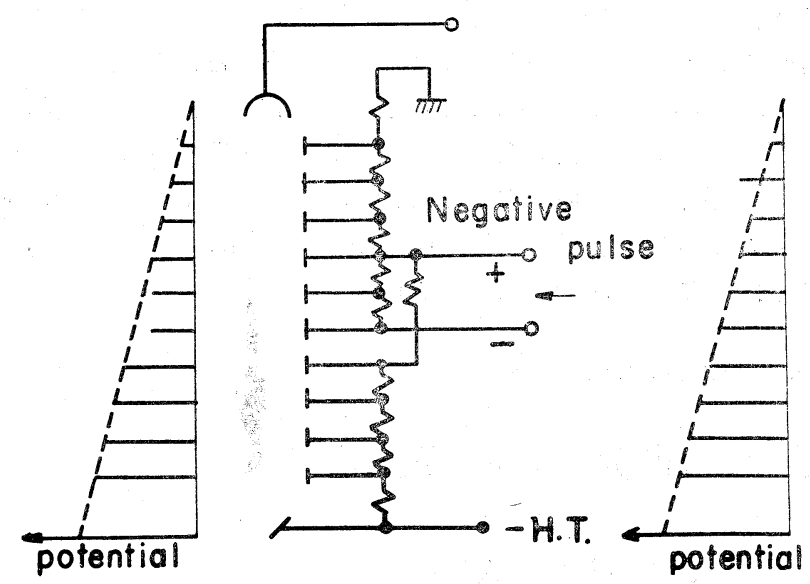

a)

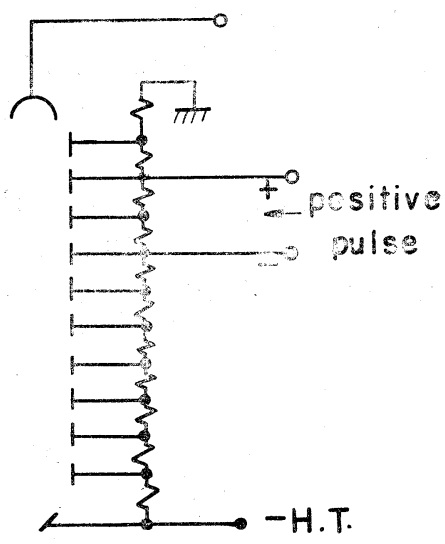

b)

Fig. 1. Gating connections of dynodes of photomultiplier.

からずらせて光電子の流れ定止めておき，ゲートを開く 時にだけ，正常な配置にもって来ればよい。ゲート動作 を行なうための接続と，2 次電子放射電極の電位配置を Fig. 1 亿示す. 図の電位配置は光電流を阻止している 状態の配置である. a) は近2) らの行なった接続で，b) は筆者らの行なった接続である. 近らの方法では, 電子 流を阻止するため 3 ケの 2 次電子放射電極を等電位にし ているが, 筆者らの方法では, 1 ケの 2 次電子放射電極 を，その前段の電極汶対して負電位に扮いている.

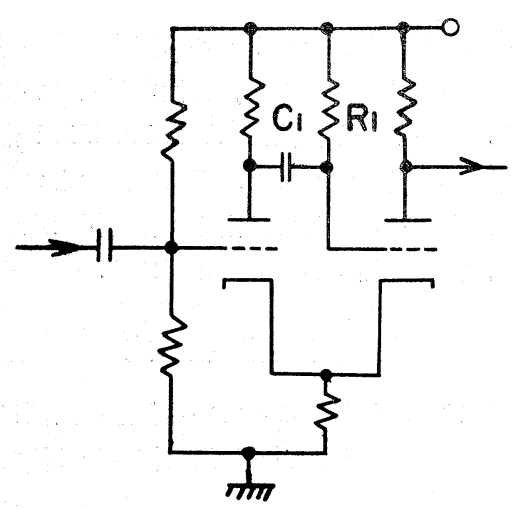

Fig. 2. Basic circuit of monostable multivibrator.

パルス発生装置のトリガ信号検出部には 1 段の増幅回 路を技き, 遅延回路およびゲートパルス発生回路には陰 極結合形の単安定マルチバイブレータを採用した。Fig. 2 は陰極結合形単安定マルチバイブレータの基本回路で ある. マルチバイブレータの性能を左右する量として, transition speed があり，これが大であることが望なし い.マルチバイブレータを構成する 2 つ真空管回路の 等価格子静電容量を $C_{1}{ }^{\prime}, C_{2}{ }^{\prime}$ とすると, transition speed は, 一次的には, $g_{m}{ }^{2} / C_{1}{ }^{\prime} C_{2}{ }^{\prime}$ 依存する. $g_{m}$ 注真空管 の相互コングクタンスである. したがって, transition speed 孛大きくするためには， $C_{1}{ }^{\prime} ， C_{2}{ }^{\prime}$ を小さくするた め, 格子-大地, 陽極一大地, 陽極-格子の浮遊静電容量 を小さくすることと，真空管を $g_{m}$ の高い状態で使うこ と,すなわち，陽極抵抗を比較的小さく選えで，高い電 流を流してやることが必要である。一般に入手が容易な 真空管で $0.5 \mu \mathrm{sec}$. の transition time を得ることは 容易で， $0.05 \mu \mathrm{sec}$. 位までは可能であるといわ机てい る. 単安定マルチバイブレータの出すパルスの怆, $R_{1} \cdot C_{1}$ で与兄られる. $R_{1}$ または $C_{1}$ の值を変化させるこ とにより，パルスの币を変化させることができる.

Fig. 3 は, パルス発生装置の電源を除く全体の回路 である・V3で構成される単安定マルチバイブレータが, 遅延回路になっており， $R_{2}$ の值を変化させることによ り,この部分の出すパルス，すなわち遅延時間の変化が 行なわれる。このマルチバイブレータは, 現象の開始を 告げる正のパルスで動作させられ， $R_{2}$ の設定值によっ て与光られる一定の時間がたつと, 次段, $V_{4}$ および $V_{5}$ で構成されるゲートパルス発生用の単安定マルチバイブ レータを動作させるのであるが，そのためにはパルスの 立ち下りで, 次段に送る正のパルスを出さなければなら ない.すなわち負のパルスを出して，それの微分波形を 次段に送らなければならない，この回路では，負のパル スを得るため, 陰極から出力を取り出している.

$V_{4}, V_{5}$ のゲートパルス発生回路のうち, 特に重要な 


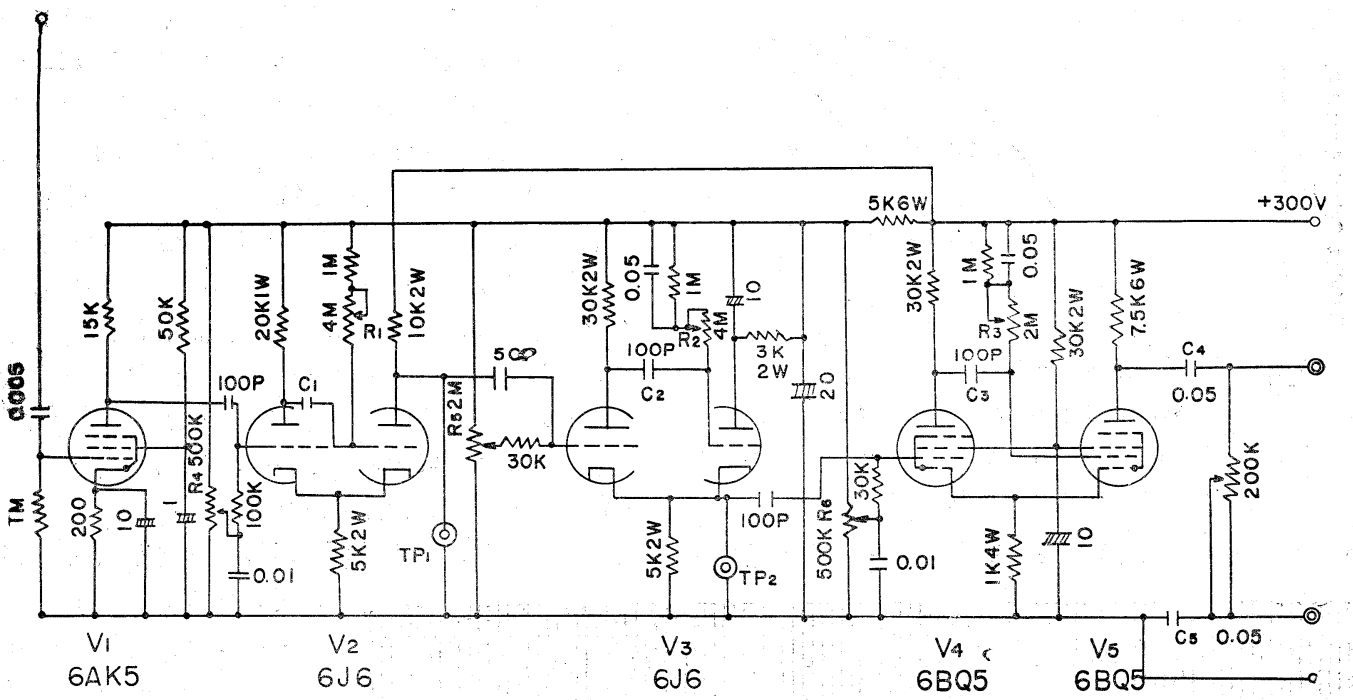

Fig. 3. Circuit diagram of pulse generator.

量は出力抵抗の值である. この部の出力が, 光電子増倍 管に印加されるのであるが，その接続導線には浮遊静電 容量があり，その浮遊静電容量と出力抵抗の積で与えら れる時定数が, 装置の出すゲートパルスの巾の限界を与 えるからである。したがってこの抵抗の值はできるだけ 小さくしたいのであるが, 出力真空管の電流容量が与え られた場合, 要求される出力電圧によって抵抗值は決っ てしまう。われわれは, 出力真空管として $6 \mathrm{BQ} 5$ を使 用し，ゲート電圧を $200 \mathrm{~V}$ とするため, 出力抵抗を $7 \mathrm{~K} \Omega$ とした.

単安定マルチバイブレータを安定に動作させるため に, 入力格子の偏奇電圧を適当に設定して, 回路の動作 点を定める必要がある. 図中, $R_{4}, R_{5}, R_{6}$ は回路の動 作点を定めるための可变抵抗器である.

光電子増倍管の 2 次電子電極にゲートパルスを印加す るとき，いずれの電極を選ぶにしても，その電極は大地 の電位にはない、したがって，ゲートパルス発生装置と 電極を直流的に切り離す必要がある. $C_{4}, C_{5}$ はこの目的 のために挿入された容量である.

第 1 段のマルチバイブレータは, 第 2 段の遅延回路が 位相決定のパルスを出し終って復帰したとき, まだ検出 部よりのトリガ信号が終っていなければ，再度動作状態 に入り発振の現象が生じるので，これを防止するため, トリガ信号が完全に終了するまで，第 2 段にトリガ信号 を送らないようにする回路で, 長いパルスを出す. ゲー トパルス発生装置の各ステップの波形を Fig. 4 に示 于.

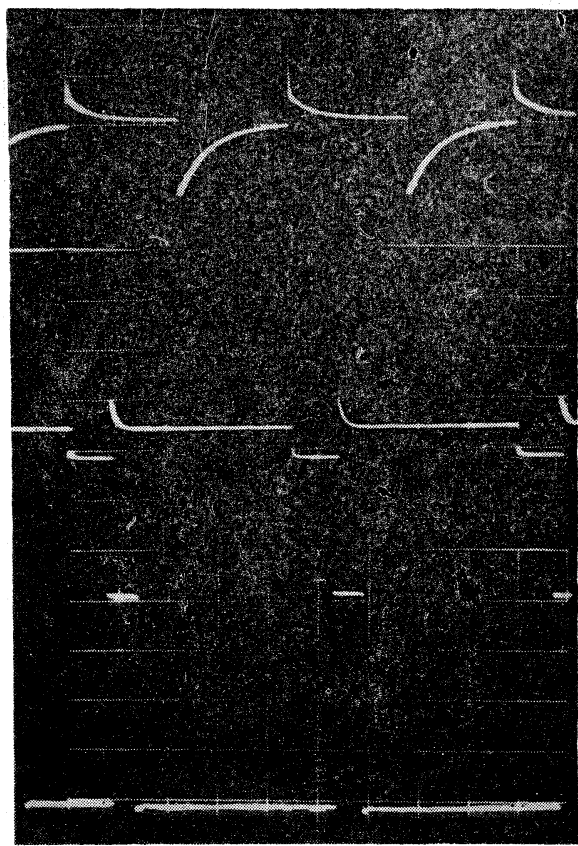

Fig. 4. Waveforms of each section of pulse generator.

a: Trigger waveform

b: Output of delay circuit

c: Gate putae

\section{3. 動 作 特 性}

動作特性のうちの問題点として，ゲート動作の安定さ と、ゲートパルスの形をとり上げる。 


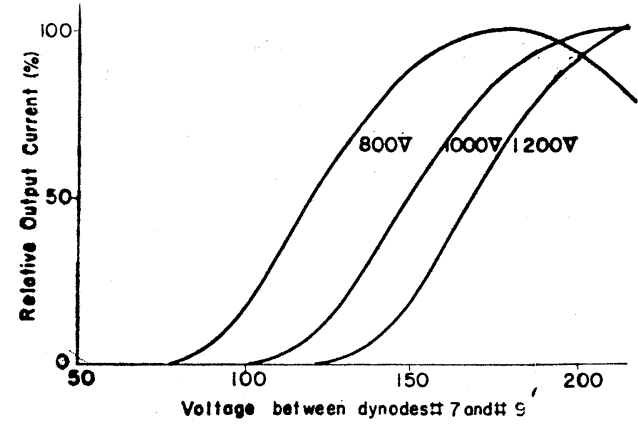

Fig. 5. Relation between gate voltage and photocurrent.

まず，動作の安定度であるが，ゲートパルスの電圧変

動が一定である場合, 光電流の安定度はゲート電圧の設 定值によって変化する. Fig. 5 は, EMI 9552 B にお いて $\# 7$ と $\$ 9$ の間 ( $\$ 9$ をゲート電極として使用) の 電圧と光電流の関係を示すものである. 最も安定なゲー ト動作の期待できるゲート電圧の值は, この曲線の傾斜 が 0 になる点であるが, その值は, 光電子増倍管に印加 する高電生の值によって変化する，したがって最も安定 な動作を行なわせるためには，印加高電圧の変化を行な うと，それに応じてゲートパルスの電圧を変化させなけ ればならない.ゲートパルスの電圧を最適値に設定した 場合と, 曲線の傾斜の大きい所に選えだ場合の安定度を 比較するため, 蓄電池で点灯されたタングステン電球の 光を, 光電子増倍管 EMI $9552 \mathrm{~B}$ の印加電圧を $1000 \mathrm{~V}$.

[2.
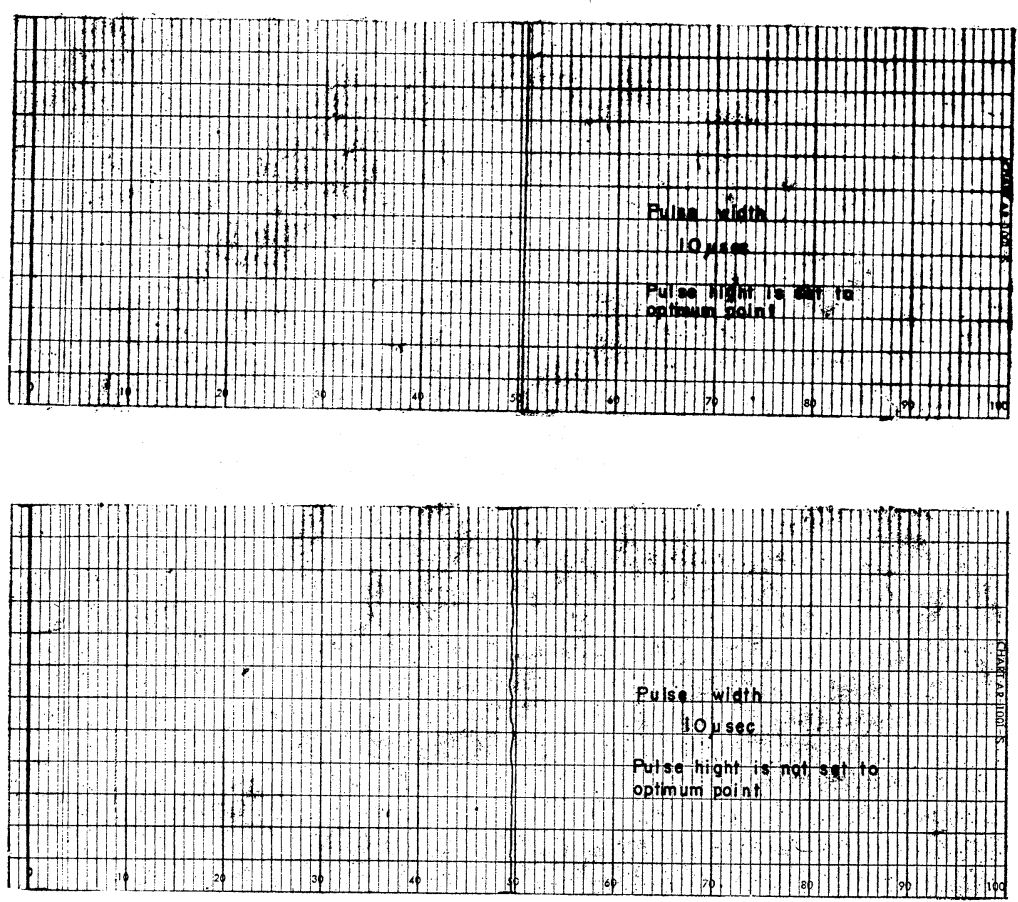

Fig. 6. Stabilities of time resolved measurements.
とし, $200 \mathrm{~V}$ (max, point), $10 \mu \mathrm{sec}$. 巾のゲートパルスで 測光したものと，他は同様な条 件で，パルスの電圧を $160 \mathrm{~V} て ゙$ 測光したときの光電流の変動を Fig. 6 に示す.

つぎに,ゲートパルスの波形 であるが，ゲートパルスの立ち 上り, 立ち下りの時間は, 発生 装置の内部抵抗と出力導線の浮 遊静電容量の積で与えられるの で, 発生装置と光電子増倍管の おかれる位置間隔によって变化 する. Fig. 7 に出力導線の長 さ（ビク口線を平行に配線して 接続）を変化したときの，波形 歪の変化を示す，われわれの試 作した装置においては, 発生端 子と光電子増倍管のゲート端子 の距離を $20 \mathrm{~cm}$ としたとき, この歪によって制限されるパル ス巾の限界值は $2 \mu \mathrm{sec}$. であ る.これをさらに小さくするこ とがのぞましいのであるが，そ のためには, さらに電流容量の 大きい出力真空管を使用して, 出力抵抗值を下げればよいと考 えられる。

本装置による時間分解測光は separated dynode 形の光電子 増倍管が用いられるところであ 
ればどこでも採用できるのであるが，極紫外分光におい ては，光電子増倍管だけで検出できない場合があり，そ のときにはサルチル酸ソーダの䖝光を用いて測光する方 法が広く採られているがこの場合，もしサリチル酸ソー ダの溃光に残光があれば問題になる. Fig. 8 はこの残 光の確認を行なうために行なった測定の略図である. 光 源として，パルス励起された水銀灯の $2537 \AA$ のスペク トル線を使用し, サリチル酸ソーダを塗布したガラス板 を用意し，それを挿入した場合と挿入しない場合の発光 波形の測定を行なった. Fig. 9 はこの測定の結果であ

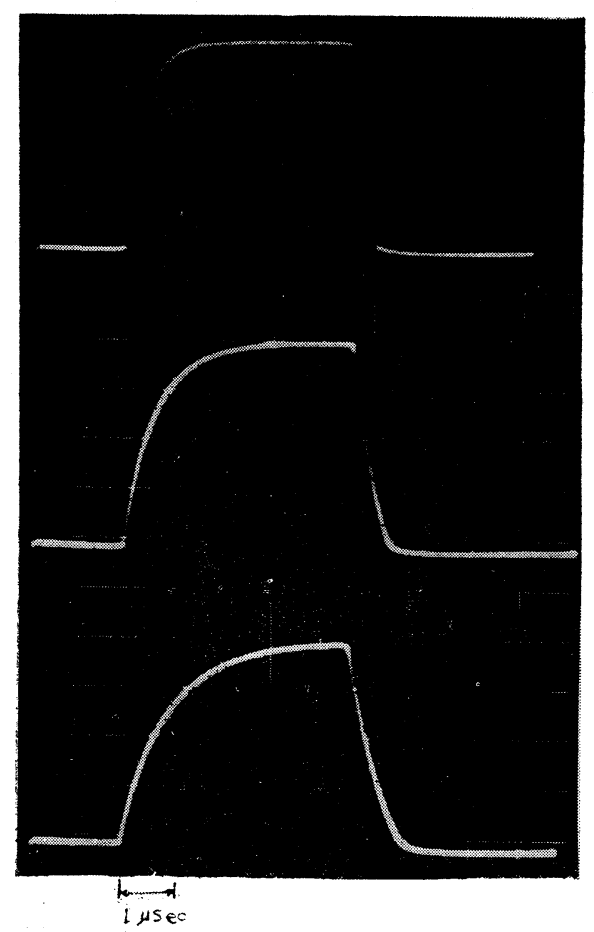

Fig. 7. Gate pulse waveforms. a: Length of lead wire is $20 \mathrm{~cm}$ b: " $\quad " 1 / 50 \mathrm{~cm}$ c: $/ 1100 \mathrm{~cm}$

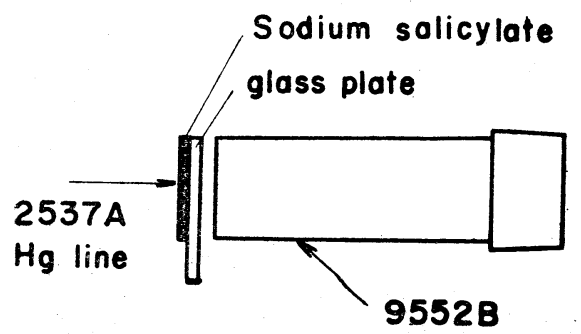

Fig. 8. Schematic diagram of afterluminesence measurement.
る. 波形測定は $2 \mu \mathrm{sec}$. の時間分解能の元で行なわれ たのであるが, この時間分解の範囲においては, 残光の 問題は無視してよいことがわかる。

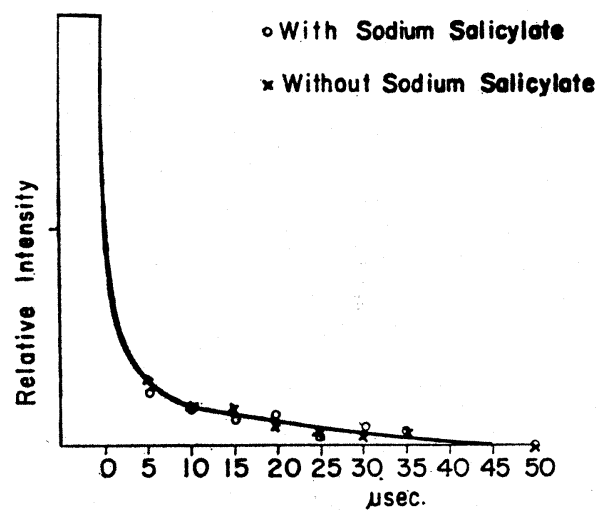

Fig. 9. Afterglow waveforms of mercury line

\section{4. 測定について}

光電子増倍管の出力をシンクロスコープで測定し, 発 光波形を求める場合には, 光電子増倍管の出力回路の浮 遊静電容量のため, 分解時間を短くしょうとすると, 負 荷抵抗を大きくすることができず，検出感度を上げるこ とが非常に困難であるが，本法による測定の場合には， 分解時間はゲートパルスの巾で与えられ，光電子増倍管 の負荷抵抗に無関係になり，負荷抵抗の值を任意に大き くすることができ，微少光量の検出が容易になる。ま たゲートパルスが印加されていない時間には, 光電子 増倍管は働いておらず，この時間の光電流は検出されな いので, 時間平均值で与えられる暗電流のレベルは, 測 定の duty ratio だけ低下し，見かけの $S / N$ の值は， ゲート動作を行なわない場合に比較して増加する・さら に, 今一つの利点として, 発光分光分析の場合に見られ るごとき，外部誘導の多い場所で測定を行なう場合に， 誘導の消去が可能であることが上げられる，時間分解が ゲートパルスで行なわれていることから，光電流測定回 路には充分大きな時定数を持たせることが出来，これが low pass filter として働くので, 高周波として入って 来る誘導を取り除くことができる.

Fig. 10 に，本装置を用いた時間分解分光測光装置の 全系の一例を示す. 図において，光電流の検出は負荷抵 抗 $(20 \mathrm{M} \Omega)$ または積分コンデンサで電圧に変えられ, この電压は入力インピータンスが無限大の電位計増巾器 によって測定され，その測定值注記録される。 


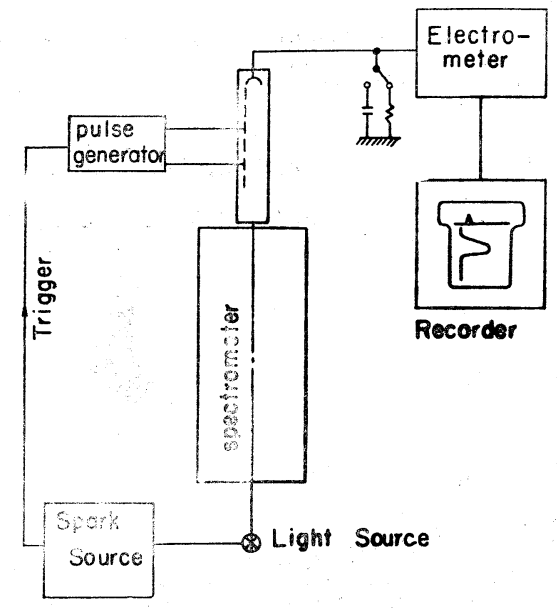

Fig. 10. Block diagram of time resolved spectroscopy.

分光器の波長を目的のスペクトル線の波長に固定し， ゲートパルスの発生位相をゅっくり变化すれば，とのス ペクトル線の波形が，ゆっくり記録される．逆に，ゲー トパルスの位相を固定し, 分光器の波長駆動を行なえ ば，その位相に打けるスペクトル線のプロフアイルを求 めることができる. Fig. 11 は，発光波形の測定を行な ったもので, Fig. 12 は $1930 \mathrm{~A}$ 付近の鉄のスペクトル 線を各位相に抢いて測定したものである.

\section{5. 結語}

この装置は，現象がくり返しである場合の時間分解測

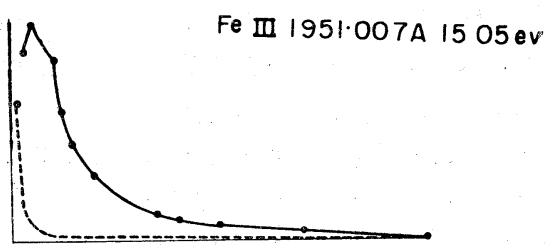

Fe I

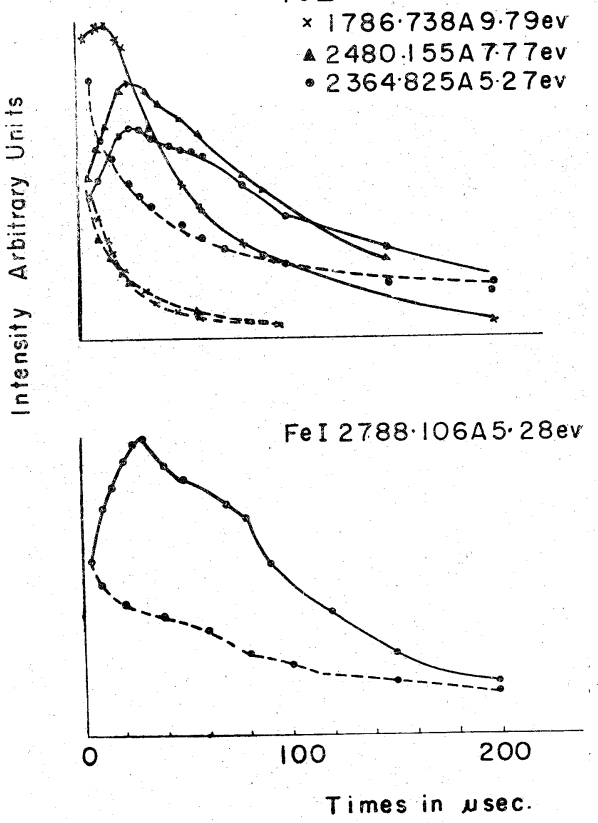

Fig. 11. Emmission waveforms of iron spectral lines.

定に対して，いくつかの利点を持った装置 であり，発光分光分析の光源に見られる ごとく, 現実に測定対象となるものには, くり返し現象として报ってよいものが多 いので，測定に応用できる機会は多いと考 えられる。

この種の装置において，今後解決しなけ ればならない問題点は少なくなく，その一 つとして，分解時間の限界の問題がある. 光電子増倍そのものの分解時間は $10^{-8}$ sec. の桁だといわれておりわれわれの試作し た装置のそれに比較すると， 2 桁も長い。 分解時間を短くするということは容易では ないと思われるが，乙れを少しでも短くす ることにより, 測定可能の現象の範囲が大 巾に広がるであるう。

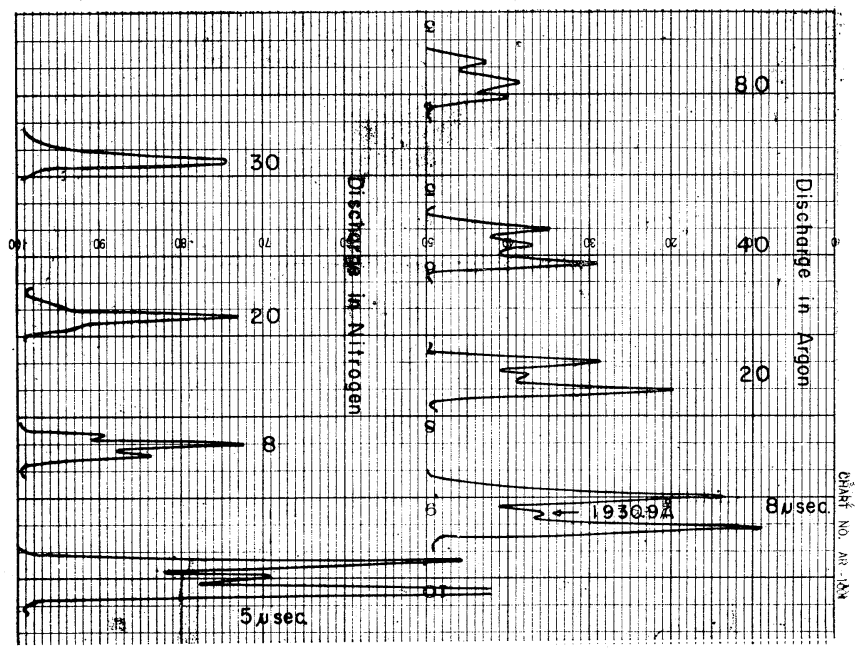

Fig. 12. Profile of iron lines about $1931 \mathrm{~A}$ 